\title{
RESPIRATORY SYMPTOMS IN FISH PROCESSING WORKERS ON THE ADRIATIC COAST OF CROATIA
}

\author{
Eugenija ŽUŠKIN ${ }^{1}$, Josipa KERN² ${ }^{2}$ Jadranka MUSTAJBEGOVIĆ ${ }^{1}$, Jasna PUCARIN- \\ CVETKOVIĆ ${ }^{1}$, Jagoda DOKO-JELINIĆ ${ }^{1}$, and Tihomir BRADIĆ ${ }^{3}$ \\ Department of Environmental and Occupational Health ${ }^{l}$, Department of Medical Statistics, Epidemiology and Medical \\ Informatics ${ }^{2}$ Andrija Štampar School of Public Health, Zagreb University School of Medicine; Clinical Hospital \\ Centre Merkur, Clinic of Internal Medicine, Zagreb, Croatia
}

Received in January 2012

CrossChecked in May 2012

Accepted in May 2012

\begin{abstract}
This article describes respiratory symptoms and lung function in 98 fish processing female workers employed in a fish processing plant located on the Croatian Adriatic coast and 95 matching controls. The study included chronic and acute respiratory symptoms which developed during the shifts. Lung function measurements included forced vital capacity (FVC), one-second forced expiratory volume $\left(\mathrm{FEV}_{1}\right)$ and maximal expiratory rates at $50 \%$ and the last $25 \%\left(\mathrm{FEF}_{50}, \mathrm{FEF}_{25}\right)$. Chronic respiratory symptoms were significantly dominant in fish processing workers compared to controls. The most common chronic symptoms were hoarseness $(57.1 \%)$, nasal catarrh $(51.0 \%)$, chronic cough $(42.9 \%)$, chronic phlegm (34.7\%), and frequent chest cold (35.7\%). Exposed smokers and nonsmokers had a similar prevalence of chronic respiratory symptoms. Acute symptoms over the work shift were high, with headache in lead (smokers: $62.5 \%$; nonsmokers: $56.1 \%$ ). Most of the ventilatory capacity parameters were significantly lower than predicted, $\mathrm{FEF}_{25}$ in particular, indicating obstructive changes predominantly in the smaller airways. These findings suggest that fish processing workers are prone to developing acute and chronic respiratory symptoms as well as to lung function changes. This calls for medical and technical preventive measures to be introduced in the work environment of the fish processing plant.
\end{abstract}

KEY WORDS: bioaerosols, occupational respiratory diseases, prevention

Fisheries along the Croatian Adriatic coast have a long tradition in processing fish such as tuna, sea bass, and sardines. Processing in the studied plant mostly includes manual handling of seafood. In Croatia, fish processing has been regulated by the Croatian veterinary and health regulation for breeding, production and marketing of fish and fish products (1, 2). According to these regulations, fish has to be sorted and cooled down to the temperature between $0{ }^{\circ} \mathrm{C}$ to $+4{ }^{\circ} \mathrm{C}$ or frozen to $-18{ }^{\circ} \mathrm{C}$. Fish processed in factories should be exsanguinated, decapitated, stripped of fins and entrails, and finally cooled or frozen.

There is an increasing demand for seafood in the world which has led to increased harvesting. The Adriatic Sea offers a great opportunity for the development of fisheries and related processing industry. Workers employed in fish processing industry are exposed to a variety of harmful environmental agents including cold and humidity, allergens, and aerosols of histamine, fish flour and other toxins. These agents may cause a number of adverse reactions. 
There are few reports on the respiratory reactions in workers occupationally exposed to harmful agents in fish processing industry. Common occupational symptoms in fish processing workers include asthma, chronic bronchitis, conjuctivitis, rhinitis, angioedema, and rash (3).

This article presents a study of respiratory function in workers employed in a fish processing plant in coastal Croatia.

\section{SUBJECTS AND METHODS}

\section{Subjects}

The study included 98 women who worked in a sardine processing plant located near the town of Zadar, Croatia. Their mean age was 44 years (range: 19 to 56 years), mean height $163 \mathrm{~cm}$ (range: $155 \mathrm{~cm}$ to $188 \mathrm{~cm}$ ) and mean years of service in fish processing industry 20 (range: 1 to 34 years). Over half the workers (52 of $98 ; 53.1 \%$ ) smoked on average 18 pack-years. As their jobs involved a variety of tasks they could not be grouped according to the working process.

The control group consisted of 95 female food packers from another plant unexposed to known bioaerosols to control for the prevalence of chronic respiratory symptoms. They matched the exposed group in age, years of service, and smoking habits.

\section{Respiratory symptoms}

Chronic respiratory symptoms were established using the Medical Research Council Questionnaire (MRCQ) (4) on respiratory symptoms and additional questions on occupational asthma, as described by Godnić-Cvar (5). All workers gave a detailed occupational and smoking history. The definitions of symptoms were taken from (4), as follows:

- Chronic cough or phlegm: cough and/or phlegm to a minimum of three months a year;

- Chronic bronchitis: cough and phlegm for a minimum of three months a year and for not less than 2 successive years;

- Dyspnea grades: grade 3 - shortness of breath when walking with other people at an ordinary pace on level ground; grade 4 - shortness of breath when walking at their own pace on level ground;

- Occupational asthma: recurring attacks of dyspnoea, chest tightness, and pulmonary function impairment of the obstructive type diagnosed by physical examination, and spirometry during or after the shift (a drop in FEV by more than $15 \%$ ), confirmed by the medical records from industrial physician.

- Chest cold: frequent cold during or after the shift for at least three months a year.

Acute symptoms that developed during the shift were also recorded in all fish processing workers, but not controls. Symptoms included cough, wheezing, chest tightness, dyspnoea, irritation or dryness of the throat, secretion, dryness or bleeding of the nose, eye irritation, and headache. Special attention was paid to register the symptoms of the reactive airways dysfunction syndrome (RADS) including cough, nasal symptoms, chest tightness, wheezing, dyspnoea, hoarseness, and throat irritation or dryness.

\section{Ventilatory capacity}

Ventilatory capacity was measured only in fish processing workers by recording maximum expiratory flow-volume (MEFV) curves on a Jaeger Pneumoscreen spirometer (Wurzburg, Germany). The MEFV curves provided information on the forced vital capacity (FVC), one-second forced expiratory volume $\left(\mathrm{FEV}_{1}\right)$, and maximum flow rates at $50 \%$ and the last $25 \%$ of the vital capacity $\left(\mathrm{FEF}_{50}\right.$ and $\mathrm{FEF}_{25}$, respectively). These readings were taken during the morning shift. The spirometer was calibrated on a daily basis. Lung function was tested according to Quanjer et al. (6). At least three MEFV curves were recorded for each subject and the best the three curves used for interpretation. Ventilatory capacity was compared with the predicted normal values proposed by Quanjer et al. (7).

\section{Statistical analysis}

Chi-square test (or when appropriate Fisher's exact test) was used to test differences in the prevalence of respiratory symptoms between the fishery and control workers . Odds ratios and $95 \%$ confidence intervals (CI) were calculated using a logistic regression analysis for each respiratory symptom (variables) and age, length of employment and smoking as predictors (8). Ventilatory capacity was analysed with the paired $t$-test by comparing baseline to predicted values (matched by sex, age, and height). Multiple regression analysis was used to adjust the predicted FVC, $\mathrm{FEV}_{1}$, $\mathrm{FEF}_{50}$, and $\mathrm{FEF}_{25}$ for sex, age, years of service, and smoking (9). A level of $\mathrm{P}<0.05$ was considered statistically significant. 


\section{RESULTS}

Table 1 shows that the prevalence of most chronic respiratory symptoms was significantly higher in fish processing workers than in controls $(\mathrm{P}<0.01)$, ranging from $57.1 \%$ for hoarseness to $2 \%$ for dyspnoea grade 3 and 4 . No case of occupational asthma was recorded in either group.

Differences in chronic respiratory symptoms between smoking and nonsmoking fishery workers are presented in Table 2. Only chronic cough was significantly higher in smokers $(56.3 \%)$ than in nonsmokers $(36.4 \%)(\mathrm{P}<0.05)$.

Acute symptoms in the fishery workers recorded during the shift did not differ significantly between smokers and nonsmokers, except for eye irritation, which was higher in nonsmokers $(57.6 \%)$ than smokers $(31.5 \%, \mathrm{P}<0.05$, Table 3$)$. No case of wheezing or chest tightness was recorded in either subgroup.

Table 4 presents the odds ratios for chronic and acute respiratory symptoms in relation to age, length of occupational exposure (years of service), and smoking. Statistically significant were the ratios for chronic cough, chronic phlegm, chronic bronchitis, and dyspnoea for smokers and for dyspnoea, nasal catarrh, acute cough, throat irritation, nasal secretion, dry nose, and headache for the length of occupational exposure (years of service).

Ventilatory capacity in fishery workers was significantly lower than predicted for all parameters, $\mathrm{FEF}_{25}$ in particular. This points to obstructive changes in the smaller airways (Table 5).

Regression analysis showed that $\mathrm{FVC}$ and $\mathrm{FEV}_{1}$ were significantly related to years of exposure

Table 1 Prevalence of chronic respiratory symptoms in 98 female fish processing workers and 95 controls

\begin{tabular}{lccc}
\hline & \multicolumn{2}{c}{ No. (\%) of subjects } & \\
\cline { 2 - 4 } Respiratory symptoms & $\begin{array}{c}\text { Fish } \\
\text { workers* } \\
(\mathbf{n = 9 8 )}\end{array}$ & $\begin{array}{c}\text { Controls }^{\dagger} \\
(\mathbf{n = 9 5 )}\end{array}$ & P \\
\hline Chronic cough & $42(42.9)$ & $6(6.1)$ & $<0.01$ \\
\hline Chronic phlegm & $34(34.7)$ & $5(5.3)$ & $<0.01$ \\
\hline Chronic bronchitis & $26(26.5)$ & $4(4.2)$ & $<0.01$ \\
\hline Dyspnoea grades 3 \& & $2(2.0)$ & $0(0)$ & $<0.01$ \\
\hline Sinusitis & $31(31.6)$ & $2(2.1)$ & $<0.01$ \\
\hline Nasal catarrh & $50(51.0)$ & $1(1.1)$ & $<0.01$ \\
\hline Choarseness & $56(57.1)$ & $0(0)$ & $<0.01$ \\
\hline
\end{tabular}

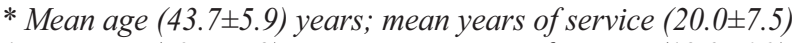

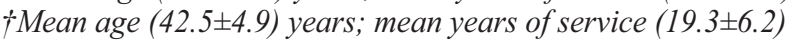

Table 2 Prevalence of chronic respiratory symptoms in 98 female fish processing workers by smoking habit

\begin{tabular}{|c|c|c|c|}
\hline \multirow[b]{2}{*}{ Respiratory symptoms } & \multicolumn{2}{|c|}{ No. ( \%) of subjects } & \multirow[b]{2}{*}{$\mathbf{P}$} \\
\hline & $\begin{array}{c}\text { Smokers* } \\
(\mathrm{n}=32)\end{array}$ & $\begin{array}{c}\text { Non-smokers }^{\dagger} \\
(n=66)\end{array}$ & \\
\hline Chronic cough & $18(56.3)$ & $24(36.4)$ & $<0.05$ \\
\hline Chronic phlegm & $14(43.8)$ & $20(30.3)$ & NS \\
\hline Chronic bronchitis & $12(37.5)$ & $14(21.2)$ & NS \\
\hline Dyspnoea grades 3 \& 4 & $1(3.1)$ & $1(1.5)$ & NS \\
\hline Sinusitis & $10(31.3)$ & $21(31.8)$ & NS \\
\hline Nasal catarrh & $15(46.9)$ & $35(53.0)$ & NS \\
\hline Hoarseness & $17(53.1)$ & $39(59.1)$ & NS \\
\hline Chest cold & $12(37.5)$ & $23(34.9)$ & NS \\
\hline
\end{tabular}

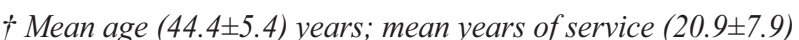

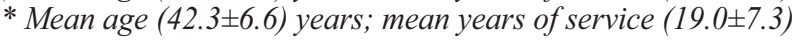


Table 3 Prevalence of acute symptoms reported during shift in 98 female fish processing workers by smoking habit

\begin{tabular}{|c|c|c|c|c|}
\hline \multirow{2}{*}{\multicolumn{2}{|c|}{ Respiratory symptoms }} & \multicolumn{2}{|c|}{ No. (\%) of subjects } & \multirow[b]{2}{*}{$\mathbf{P}$} \\
\hline & & \multirow{2}{*}{$\begin{array}{c}\begin{array}{c}\text { Smokers* } \\
(\mathbf{n}=\mathbf{3 2})\end{array} \\
1(3.1)\end{array}$} & $\begin{array}{c}\text { Non-smokers }{ }^{\dagger} \\
(n=66)\end{array}$ & \\
\hline Cough & & & $1(1.5)$ & NS \\
\hline Dyspno & & $1(3.1)$ & $1(1.5)$ & NS \\
\hline \multirow{2}{*}{ Throat } & irritation & $12(37.5)$ & $19(28.8)$ & NS \\
\hline & dryness & $16(50.0)$ & $32(48.5)$ & NS \\
\hline \multicolumn{2}{|c|}{ Eye irritation } & $10(31.3)$ & $38(57.6)$ & $<0.01$ \\
\hline \multirow{3}{*}{ Nose } & secretion & $4(12.5)$ & $13(19.7)$ & NS \\
\hline & dryness & $5(15.6)$ & $12(18.2)$ & NS \\
\hline & bleeding & $5(15.6)$ & $8(12.1)$ & NS \\
\hline \multicolumn{2}{|c|}{ Headache } & $20(62.5)$ & $37(56.1)$ & NS \\
\hline
\end{tabular}

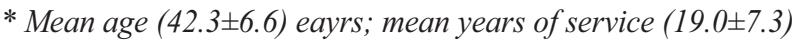

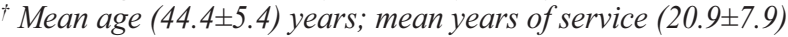

Table 4 Chronic respiratory and acute symptoms in 98 female fish processing workers in relation to age, years of service, and smoking by log regression

\begin{tabular}{|c|c|c|c|}
\hline \multirow[b]{2}{*}{ Symptoms } & \multicolumn{3}{|c|}{ OR (95 \% CI) } \\
\hline & Age & Exposure & Smoking \\
\hline Chronic cough + & $1.055(0.964$ to 1.155$)$ & $0.950(0.887$ to 1.017$)$ & $1.096 *(1.010$ to 4.071$)$ \\
\hline Chronic phlegm + & $1.001(0.914$ to 1.096$)$ & $0.990(0.924$ to 1.061$)$ & $1.102 *(0.081$ to 5.076$)$ \\
\hline Chronic bronchitis + & $1.034(0.937$ to 1.141$)$ & 0.975 (0.907 to 1.049$)$ & $1.040 *(1.000$ to 1.092$)$ \\
\hline Dyspnoea + & $0.902(0.596$ to 1.365$)$ & $1.077 *(1.011$ to 4.525$)$ & $1.032 *(1.023$ to 6.153$)$ \\
\hline Sinusitis + & $1.053(0.957$ to 1.159$)$ & $0.985(0.920$ to 1.055$)$ & $1.004(0.959$ to 1.051$)$ \\
\hline Nasal catarrh + & 0.973 (0.888 to 1.067$)$ & $1.103 *(1.097$ to 5.149$)$ & $0.980(0.936$ to 1.026$)$ \\
\hline Hoarseness+ & $1.072(0.975$ to 1.179 & $1.019(0.951$ to 1.091$)$ & 0.969 (0.926 to 1.014$)$ \\
\hline Chest cold + & $0.965(0.879$ to 1.060$)$ & $1.020(0.950$ to 1.096$)$ & $1.000(0.954$ to 1.048$)$ \\
\hline Acute cough++ & $0.358(0.074$ to 1.744$)$ & $2.550 *(1.135$ to 1.207$)$ & $0.849(0.410$ to 1.755$)$ \\
\hline Throat irritation++ & 0.943 (0.844 to 1.054$)$ & $1.188 *(1.085$ to 7.173$)$ & $1.030(0.980$ to 1.081$)$ \\
\hline Dry throat ++ & $1.018(0.933$ to 1.111$)$ & $1.011(0.926$ to 1.056$)$ & $0.996(0.953$ to 1.042$)$ \\
\hline Eye irritation++ & $1.098(0.995$ to 1.212$)$ & $1.003(0.936$ to 1.075$)$ & 0.958 (0.911 to 1.007$)$ \\
\hline Nasal secretion++ & $0.931(0.871$ to 1.111$)$ & $1.148 *(1.090$ to 9.324$)$ & 0.977 (0.914 to 1.045$)$ \\
\hline Dry nose++ & $0.946(0.834$ to 1.074$)$ & $1.037 *(1.010$ to 5.146$)$ & 0.975 (0.901 to 1.054$)$ \\
\hline Nasal bleeding ++ & $0.970(0.862$ to 1.091$)$ & $0.970(0.883$ to 1.065$)$ & 1.004 (0.936 to 1.079$)$ \\
\hline Headache++ & $1.005(0.920$ to 1.099$)$ & $1.048 *(1.010$ to 1.122$)$ & 0.987 (0.943 to 1.033$)$ \\
\hline
\end{tabular}

OR $=$ odds ratio

$C I=$ confidence interval

$* P<0.01$ or $P<0.05$

+chronic symptoms

++ acute symptoms

(service) while none was significantly related to smoking (Table 6).

\section{DISCUSSION}

Fish processing workers are exposed to several occupational health and safety risks, and fish aerosols in the working environment present a risk for the development of respiratory diseases. Other agents that can cause respiratory diseases or allergic sensitisation include fish enzymes, proteins or skin.

Sherson et al. (10) demonstrated occupational respiratory or rhinitis symptoms, caused by inhalation of fish aerosols, in trout-processing factory workers who worked next to an automatic gutting machine. Shiryaeva et al. (11) recently established impaired lung function in fishermen. Bang et al. (12) reported high prevalence of work-related airway symptoms $(42.8 \%)$ in sea food industry workers. In their study, $\mathrm{FVC}$ and $\mathrm{FEV}_{1}$ were lower than the predicted values 
Table 5 Ventilatory capacity in 98 female fish processing workers by smoking habit

\begin{tabular}{|c|c|c|c|}
\hline \multirow{2}{*}{\multicolumn{2}{|c|}{ Ventilatory capacity }} & \multicolumn{2}{|c|}{ No. of subjects } \\
\hline & & Smokers* & Non-smokers ${ }^{\dagger}$ \\
\hline \multirow{4}{*}{$\mathrm{FVC}$} & Measured (L) & $3.2 \pm 0.6$ & $3.1 \pm 0.6$ \\
\hline & Predicted (L) & $3.6 \pm 0.3$ & $3.5 \pm 0.3$ \\
\hline & $\begin{array}{l}\text { Difference measured- } \\
\text { predicted } \%\end{array}$ & $89.2 \pm 14.0$ & $88.9 \pm 12.3$ \\
\hline & $\mathrm{P}$ & $<0.01$ & $<0.01$ \\
\hline \multirow{4}{*}{$\mathrm{FEV}_{1}$} & Measured (L) & $2.8 \pm 0.4$ & $2.7 \pm 0.5$ \\
\hline & Predicted (L) & $2.9 \pm 0.2$ & $2.8 \pm 0.3$ \\
\hline & $\begin{array}{l}\text { Difference measured- } \\
\text { predicted } \%\end{array}$ & $97.7 \pm 13.0$ & $98.7 \pm 14.1$ \\
\hline & $\mathrm{P}$ & $<0.01$ & $<0.01$ \\
\hline \multirow{4}{*}{$\mathrm{FEF}_{50}$} & Measured (L) & $3,9 \pm 0.9$ & $3.8 \pm 0.9$ \\
\hline & Predicted (L) & $4.2 \pm 0.1$ & $4.2 \pm 0.2$ \\
\hline & $\begin{array}{l}\text { Difference measured- } \\
\text { predicted } \%\end{array}$ & $91.2 \pm 18.7$ & $91.4 \pm 22.9$ \\
\hline & $\mathrm{P}$ & $<0.01$ & $<0.01$ \\
\hline \multirow{4}{*}{$\mathrm{FEF}_{25}$} & Measured (L) & $1.7 \pm 0.4$ & $1.8 \pm 0.5$ \\
\hline & Predicted (L) & $2.1 \pm 0.1$ & $2.0 \pm 0.1$ \\
\hline & $\begin{array}{l}\text { Difference measured- } \\
\text { predicted } \%\end{array}$ & $80.7 \pm 17.5$ & $87.5 \pm 25.9$ \\
\hline & $\mathrm{P}$ & $<0.01$ & $<0.01$ \\
\hline
\end{tabular}

The measured date are presented as mean $\pm S D$

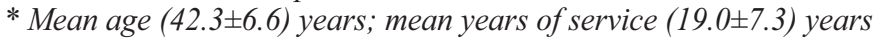

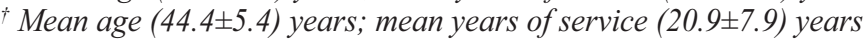

Table 6 Regression analysis of ventilatory capacity tests in 98 female fish processing workers

\begin{tabular}{|c|c|c|c|c|c|c|c|c|c|}
\hline Test & Variable & DF & $\begin{array}{l}\text { Parameter } \\
\text { Estimate }\end{array}$ & $\begin{array}{c}\text { Standard } \\
\text { Error }\end{array}$ & $\begin{array}{c}\text { T for } \mathrm{HO}: \\
\text { Parameter }=0\end{array}$ & Prob $>(T)$ & $\mathbf{F}$ & $\mathbf{P}$ & $\mathbf{R}^{2}$ \\
\hline \multirow{3}{*}{ FVC } & intercept & 1 & 3.74365 & 0.15282 & 24.37 & $<0.0001$ & & & \\
\hline & exposure & 1 & -0.02994 & 0.00706 & -4.24 & $<0.0001$ & & & \\
\hline & smoking & 1 & 0.00645 & 0.00603 & 1.07 & 0.2873 & 9.18 & 0.0002 & 0.1443 \\
\hline \multirow{3}{*}{$\mathrm{FEV}_{1}$} & intercept & 1 & 3.11190 & 0.12392 & 25.11 & $<0.0001$ & & & \\
\hline & exposure & 1 & -0.01804 & 0.00573 & -3.15 & 0.0022 & & & \\
\hline & smoking & 1 & 0.00313 & 0.00489 & 0.64 & 0.5240 & 5.01 & 0.0086 & 0.0763 \\
\hline \multirow{3}{*}{$\mathrm{FEF}_{50}$} & intercept & 1 & 4.15705 & 0.26216 & 15.86 & $<0.0001$ & & & \\
\hline & exposure & 1 & -0.01486 & 0.01211 & -1.23 & 0.2228 & & & \\
\hline & smoking & 1 & -0.00364 & 0.01035 & -0.35 & 0.7258 & 0.87 & 0.4216 & -0.0027 \\
\hline \multirow{3}{*}{$\mathrm{FEF}_{25}$} & intercept & 1 & 1.84040 & 0.14036 & 13.11 & $<0.0001$ & & & \\
\hline & exposure & 1 & -0.00212 & 0.00649 & -0.33 & 0.7450 & & & \\
\hline & smoking & 1 & -0.01056 & 0.00554 & -1.91 & 0.0596 & 1.96 & 0.1463 & 0.0194 \\
\hline
\end{tabular}

$T$ - $t$-statistics for the null hypothesis

$\mathrm{HO}$ - the parameter is 0

Exposure - length of service

in all exposed nonsmokers. This supports our findings of lower ventilatory capacity tests. In addition, sickleave rate was higher among our fish-processing workers than controls (data not shown).
Pre-employment and periodic medical examination of workers in fish processing plant as well as improved ventilation in the processing areas should help to prevent the development of acute and chronic 
respiratory changes. Early symptom recognition and prompt action to reduce aerosol exposure should further help to avoid chronic changes in pulmonary function, often associated with occupational asthma. In that respect symptoms of the upper airways can be a reliable risk marker for workers exposed to highmolecular-weight agents such as seafood. Lung function tests can help to determine which workers have hyper-responsive airways.

The association between respiratory health effects and environmental concentrations of seafood aerosols helps to identify who is at a higher risk of developing occupational asthma. In addition, the preventive measures should include anti-smoking programmes.

Currently there are no occupational exposure limits for seafood aerosols, local or international, and setting them would definitely contribute to health protection of workers in the seafood industry.

\section{REFERENCES}

1. Pravilnik o veterinarsko-zdravstvenim uvjetima koje moraju ispunjavati objekti za uzgoj, proizvodnju i stavljanje u promet riba i proizvoda od riba te rakova i proizvoda od rakova [Ordinance on veterinary health conditions, requirements to be fulfilled by establishments for breeding, production and placing on the market of fish and fish products as well as shellfish and shellfish products, in Croatian]. Narodne novine 148/1999.

2. Pravilnik o provedbenim mjerama koje se odnose na zabranu recikliranja riba unutar istih vrsta, zakapanja i spaljivanja nusproizvoda životinjskog podrijetla [Ordinance on the implementing measures as regards the intra-species recycling ban for fish, the burrial and burning of animal by-products, in Croatian]. Narodne novine 96/2009.

3. Jeebhay MF, Cartier A. Seafood workers and respiratory diseases: an update. Curr Opin Allergy Clin Immunol 2010;10:104-13.

4. Cotes JE, Chinn DJ. Medical Research Council Questionnaire (MRCQ) on respiratory symptoms. Occupational Medicine 2007;57:388; doi:10.1093/occmed/kqm051

5. Godnic-Cvar J. How to confirm occupational asthma. Int Arch Occup Environ Health 1995;67:79-84.

6. Quanjer PH, Tammeling GJ, Cotes JE, Pedersen OF, Peskin R, Yernault JC. Lung volumes and forced ventilatory flows. Report of the Working Party «Standardization of Lung Function Tests». European Community for Steel and Coal. Eur Respir J 1993;Suppl 16:5-40.

7. Quanjer PH. Standardized lung function test of the European Committee for Coal and Steel. Bull Eur Physiopathol Respir 1983;19(Suppl 5):1-95.

8. Statistical Analysis Systems Institute. SAS/STAT User's Guide. release 6.05 ed. Cary, NC: SAS; 1988:1028.

9. Statistical Analysis Systems Institute. SAS Technical Report p-200. SAS/STAT Software: Calis and Logistic Procedures. release 6.04 ed. Cary, NC: SAg;1990:236.

10. Sherson D, Hansen I, Sigsgaard T. Occupationally related respiratory symptoms in trout-processing workers. Allergy 1989;44:336-41.

11. Shiryaeva O, Aasmoe L, Straume B, Bang BE. An analysis of the respiratory health status among seafarers in the Russian trawler and merchant fllets. Am J Ind Med 2011;54:971-9.

12. Bang B, Aasmoe L, Aamodt BH, Aardal L, Andorsen GS, Bolle R, Bøe R, Van Do T, Evans R, Florvåg E, Gram IT, Huser PO, Kramvik E, Løchen ML, Pedersen B, Rasmussen T. Exposure and airway effects of seafood industry workers in northern Norway. J Occup Environ Med 2005;47:48292. 


\section{Sažetak}

\section{RESPIRATORNI SIMPTOMI U RADNICA NA PRERADI RIBA NA OBALI JADRANA U HRVATSKOJ}

Cilj je ovoga istraživanja bio ispitati respiratorne simptome i plućnu funkciju radnica zaposlenih na preradi riba u industriji na obali Jadranskog mora u Hrvatskoj. U istraživanje je uključeno 98 radnica zaposlenih na preradi riba i 95 žena neizložene kontrolne skupine. Ispitivani su kronični i akutni respiratorni simptomi koji se razvijaju tijekom radne smjene. Mjerena je plućna funkcija registriranjem forsiranoga vitalnog kapaciteta $(\mathrm{FVC})$, forsiranoga ekspiracijskog volumena u prvoj sekundi $\left(\mathrm{FEV}_{1}\right)$ te maksimalnoga ekspiracijskog protoka pri $50 \%$ i zadnjih $25 \%$ forsiranoga vitalnog kapaciteta $\left(\mathrm{FEF}_{50}, \mathrm{FEF}_{25}\right)$ na krivulji maksimalni ekspiracijski protok-volumen (MEPV). Učestalost većine kroničnih respiracijskih simptoma bila je značajno viša u eksponiranih u usporedbi s kontrolnom skupinom. U eksponiranih radnica utvrđena je i visoka prevalencija akutnih simptoma koji se razvijaju tijekom radne smjene, posebno za promuklost $(57,1 \%)$ i katar nosa (51 \%), potom slijedi kronični kašalj (42,9 \%), kronični iskašljaj $(34,7$ \%), upale sinusa $(32 \%)$ i česte prehlade $(35,7 \%)$. S obzirom na naviku pušenja pušači i nepušači imali su sličnu prevalenciju kroničnih respiratornih simptoma. Izložene radnice imale su visoku prevalenciju akutnih simptoma tijekom radne smjene i to naročito za glavobolju (pušači 62,5 \%; nepušači 56,1 \%). Ventilacijska funkcija pluća bila je značajno smanjena u usporedbi s predviđenim normalnim vrijednostima posebice za FEF25 \% upućujući na opstruktivne promjene pretežno u manjim dišnim putovima. Naši podaci upućuju na opasnost razvoja kroničnih i akutnih respiracijskih simptoma i promjena plućne funkcije u radnika koji rade $u$ industriji na preradi riba. Medicinske i tehničke preventivne mjere u radnom okolišu treba preporučiti $\mathrm{u}$ industriji prerade riba.

KLJUČNE RIJEČI: bioaerosoli, prevencija, profesionalne respiratorne bolesti

\section{CORRESPONDING AUTHOR:}

Professor Eugenija Žuškin, PhD

Department of Environmental and Occupational Health Andrija Štampar School of Public Health University of Zagreb, School of Medicine Rockefellerova 4, 10000 Zagreb, Croatia E-mail: ezuskin@snz.hr 